\title{
SKRINING FARMAKOGNOSI TANAMAN ETNOFARMASI ASAL KABUPATEN BULUKUMBA YANG BERPOTENSI SEBAGAI ANTIKANKER
}

\author{
Asni Amin \\ Fakultas Farmasi Universitas Muslim Indonesia \\ email:nienieasni_apt@yahoo.com
}

\begin{abstract}
The use of traditional medicine has long been known and used by the people of South Sulawesi and recorded since the 15th century in lontara 'pabbura. Bulukumba as one of the areas of south Sulawesi inhabited by ethnic of Kajang and ethnic of Makassar has also been used plants to treat several of diseases including. Screening studies pharmacognostic origin Bulukumba conducted to identify medicinal plants used by the community Bulukumba to treat cancer. The research location is the village of Bahari Bonto Lembanna District Bulukumba, The research location is the village Lembana of Bonto Bahari District Regency of Bulukumba, the surveys plants etnofarmasi through sanro (traditional healers), public figures and society who have knowledge of traditional medicine with purposive sampling method. Pharmacognosy screening includes determination etnofarmasi plants that have been collected, organoleptic examination, morphology, anatomy and identification of chemical constituents using color reagent and precipitation reactions. The results obtained five plants etnofarmasi potential for the treatment of cancer, leaf of landep (Barleria prionitis L.) Family Acanthaceae, gewor (Basella rubra L) Famili Acanhtaceae, pecut kuda (Stachytarpheta jamaicensis) Family Loranthaceae, rumput mutiara (Hedyotis corymbosa L.) family Rubiaceae dan gondola (Commelina benghalensis L.) Family Commelinaceae, with chemical ingredients contain flavonoids, saponins, alkaloids, and tannins. The content of flavonoids and alkaloids in plants has the potential to be used as a cancer treatment.
\end{abstract}

Keywords : Etnopharmacy, anticancer, Pharmacognosy screening.

\begin{abstract}
Abstrak
Penggunaan obat tradisional telah lama dikenal dan digunakan oleh masyarakat Sulawesi Selatan dan dibukukan sejak abad ke-15 dalam lontara' pabbura. Bulukumba sebagai salah satu wilayah Sulawesi Selatan dihuni oleh etnis Makassar dan etnis Kajang juga telah menggunakan tanaman termasuk untuk mengobati berbagai penyakit. Penelitian skrining farmakognostik asal Kabupaten Bulukumba dilakukan dengan tujuan untuk mengidentifikasi tanaman obat yang digunakan oleh masyarakat Bulukumba untuk mengobati penyakit kanker. Lokasi penelitian adalah desa Lembanna Kecamatan Bonto Bahari Kabupaten Bulukumba, dengan mensurvei tanaman etnofarmasi melalui sanro (pengobat tradisional), tokoh masyarakat dan masyarakat yang memiliki pengetahuan tentang obat tradisional dengan metode purposive sampling. Skrining farmakognosi meliputi determinasi tanaman etnofarmasi yang telah dikumpulkan, pemeriksaan organoleptik, morfologi, anatomi dan identifikasi kandungan kimia menggunakan pereaksi warna dan reaksi pengendapan. Hasil penelitian didapatkan lima tanaman etnofarmasi yang potensial untuk pengobatan kanker yaitu daun landep (Barleria prionitis L.) Famili Acanthaceae, gewor (Basella rubra L) Famili Acanhtaceae, pecut kuda (Stachytarpheta jamaicensis) Famili Loranthaceae, rumput mutiara (Hedyotis corymbosa L.) family Rubiaceae dan gondola (Commelina benghalensis L.) famili Commelinaceae, dengan kandungan kimia mengandung
\end{abstract}


flavanoid, saponin, alkaloid, dan tanin. Kandungan flavonoid, dan alkaloid dalam tanaman berpotensi untuk digunakan sebagai obat kanker.

Kata Kunci : Etnofarmasi, Antikanker, Skrining farmakognosi.

\section{PENDAHULUAN}

Penggunaan bahan alam sebagai obat tradisional di Indonesia telah dilakukan oleh nenek moyang kita sejak berabad-abad lalu berdasarkan etnofarmasi yang menggunakan bahan alam sebagai obat terkait dengan penggunaannya dalam konteks kultural oleh masyarakat lokal (etnik). Hal ini terkait ciri budaya masyarakat Indonesia dengan masih dominannya unsur-unsur tradisional dalam kehidupan sehari-hari. Penggunaan bahan alam sebagai obat tradisional terbukti dari adanya naskah kuno pada daun lontar seperti Husodo (Jawa), Usada (Bali), dan Lontarak pabbura (Sulawesi Selatan). Persepsi mengenai konsep sakit, sehat, dan keragaman jenis tumbuhan yang digunakan sebagai obat tradisional terbentuk melalui suatu proses sosialisasi yang secara turun temurun dipercaya dan diyakini kebenarannya. Keadaan ini didukung oleh keanekaragaman hayati yang terhimpun dalam berbagai tipe ekosistem yang pemanfaatannya telah mengalami sejarah panjang sebagai bagian dari kebudayaan.

Meskipun penggunaan obat tradisional dari bahan alam di Sulawesi Selatan telah dibukukan sejak awal abad 15 dikenal dengan sure lontarak pabburak yang berisi jenis tanaman, khasiat dan cara penggunaannya, namun publikasi dan popularitas referensi ini seolah tertimbun bersama kemajuan zaman dengan meninggalnya tokoh-tokoh adat, dan dukun/sanro, akibatnya masyarakat Sulawesi Selatan sendiri seolah kehilangan pedoman dalam penggunaan tanaman obat yang ada disekitarnya. Sehingga perlu dilakukan penelitian etnofarmasi untuk menggali warisan budaya khususnya dalam upaya pengembangan obat tradisional dan membuktikan secara ilmiah kebenaran khasiatnya.

Salah satu cara pembuktian ilmiah akan kebenaran dalam penggunaan obat tradisional yang digunakan oleh masyarakat Bulukumba adalah dengan melakukan skrining farmaskognostik tanaman etnofarmasi yang berpotensi sebagai obat antikanker.

Bulukumba adalah salah satu wilayah di Sulawesi Selatan yang dulu berada di bawah kekuasaan kerajaan Bontobangun, yang dihuni oleh banyak kelompok etnis, tapi masih dominan bahasa Makassar sehingga dapat dianggap termasuk rumpun bahasa Makassar. Wilayah ini memiliki letak geografis dan tofografi berada pada kondisi empat dimensi yakni dataran tinggi pada kaki gunung BawakaraengLompobattang, dataran rendah, pantai dan laut lepas, sehingga sangat potensial untuk pengembangan obat bahan alam. Masyarakat di wilayah ini utamanya etnis Makassar, dan Kajang telah menggunakan tanaman untuk mengobati berbagai penyakit yang dilakukan oleh sanro, termasuk untuk mengobati penyakit kanker.

Tujuan penelitian ini adalah untuk mendeterminasi dan mengidentifikasi farmakognosi secara organoleptik, morfologi, anatomi dan komponen kimia tanaman etnofarmasi yang digunakan masyarakat Bulukumba sebagai antikanker. 


\section{METODE}

Alat: Alat-alat gelas, sentrifuge, plat tetes. Bahan : beberapa tanaman etnofarmasi asal Kabupaten Bulukumba, pereaksi IKI, Dragendorf, Luff, $\mathrm{FeCl}_{3}$, Vanilin-asam sulfat, flouroglusin, Sudan III, KOH 10\%etanol, Liberman-Buchard, Aquadest.

\section{Waktu Penelitian :}

Penelitian dilakukan pada Oktober 2009Maret 2010.

\section{Lokasi Penelitian:}

Penelitian tanaman etnofarmasi dilakukan di Desa Lembanna, Kec. Bontobahari Kabupaten Bulukumba, dan pengujian skrining farmakognosi dilakukan di Laboratorium Farmakognosi-Fitokimia Fakultas Farmasi UMI.

\section{Metode :}

1. Pengumpulan data etnofarmasi di desa Lembanna dilakukan dengan penyebaran kuisener dan wawancara dengan metode purposive sampling (informan dipilih berdasarkan pengetahuan dan pengalamannya tentang tanaman obat, yaitu dukun/sanro atau keturunannya, tokoh adat/masyakarat dan orang yang berpengalaman dalam pengobatan tradisional), semua data etno-farmasi dikumpulkan sebagi data inventarisasi tanaman obat.

2. Pengumpulan sampel tanaman dan determinasi tanaman.

3. Pemeriksaan tanaman meliputi: uji Organoleptik (bau, warna, dan rasa) dari tanaman dan simplisia, morfologi tanaman, dan anatomi berupa pemeriksaan penampang melintang dan membujur dari daun, batang dan akar.

4. Pembuatan Simplisia dengan metode pengeringan.
5. Identifikasi Kandungan kimia dengan pereaksi warna dan reaksi pengendapan untuk menguji adanya kandungan amilum/ aleuron, alkaloid, saponin, steroid, karbohidrat, glikosida, fenolik, tannin, dan flavanoid yang mengacu sesuai dengan prosedur pada Materia Medika Indonesia.

\section{a. Reaksi warna}

Reaksi warna dilakukan terhadap hasil penyaringan zat berkhasiat baik sebagai hasil mikrosublimasi atau langsung terhadap irisan serbuk simplisia :

1. Lignin: serbuk simplisia diberi larutan floroglusin $\mathrm{P}$, tambahkan asam klorida $\mathrm{P}$, diamati di mikroskop, positif terdapat sel batu jika dinding sel berwarna merah.

2. Pati / Aleuron: ditambahkan pereaksi Iodium $0,1 \mathrm{~N}$ pada bahan yang akan diperiksa, pati berwarna biru, dan aleuron berwarna kuning coklat sampai coklat.

3. Suberin, kutin, minyak menguap, dan minyak lemak : bahan yang akan diperiksa diletakkan di atas kaca objek, tambahkan beberapa tetes sudan III LP, bahan dapat dijernihkan dengan klorohidrat, kecuali bahan yang mengandung minyak atsiri.

4. Uji adanya sterol dengan reaksi Liebermen Bouchard : 10 tetes minyak lemak dan dilarutkan dalam $5 \mathrm{ml}$ kloroform, campur dan amati warna yang terjadi.

5. Selulosa: Untuk menentukan adanya selulosa bahan ditambahkan larutan seng (II) klorida beriodium, memberikan warna ungu merah.

6. Zat samak / tannin: Bahan ditambahkan besi (III) ammonium sulfat $\mathrm{P}$ encer, zat samak dan 
senyawa tanat lainnya berwarna hijau atau biru sampai hitam.

7. Katekol: Letakkan bahan atau serbuk di atas kaca objek ditambahkan larutan vanillin $\mathrm{P} 10 \% \mathrm{~b} / \mathrm{v}$ dalam etanol $90 \% \mathrm{P}$, kemudian dalam asam klorida $\mathrm{P}$, bagian yang mengandung turunan katekol berwarna merah intensif.

8. Dioksiantrakinon: Serbuk dalam tabung reaksi ditambahkan kalium hidroksida etanol LP, warna merah

9. Fenol ditentukan dengan reaksi Mikrosublimasi yaitu serbuk sampel dalam vial dilarutkan dengan air, dan ditutupi dengan objek gelas dan di atas objek gelas diberi kapas, dipanaskan hingga menyublin.

a. Hasil mikrosublimasi ditambahkan fosfo-molibdat asam sulfat LP, warna biru.

b. Hasil mikrosublimasi ditambahkan asam diazobensulfonat LP, warna biru.

10.Saponin : sebanyak $0,5 \mathrm{~g}$ serbuk dalam tabung reaksi ditambahkan 10 $\mathrm{ml}$ air panas, dinginkan kemudian kocok kuat selama 10 detik, terbentuk buih yang mantap selama 10 menit setinggi $1-10 \mathrm{~cm}$, dan penambahan 1 tetes asam hidroklorida $2 \mathrm{~N}$, buih tidak hilang.

11.Flavanoid : Sari 0,5 g serbuk dengan $10 \mathrm{ml}$ metanol dengan alat pendingin balik selama 10 menit, disaring panas, filtrate ditambahkan $10 \mathrm{ml}$ air, setelah dingin tambahkan $5 \mathrm{ml}$ eter minyak tanah $\mathrm{P}$, kocok hati-hati, diamkan. Lapisan metanol diambil dan diuapkan pada suhu $>400$ di bawah tekanan.

12.Karbohidrat: ekstrak etanol ditambahkan air $2 \mathrm{ml}$ dalam cawan porselin, diuapkan, tambahkan 2-3 tetes asam sulfat $\mathrm{P}$, diamkan selama
4 menit, tambahkan pereaksi molish, terjadi warna merah.

13.Steroid: Ekstrak metanol kering disuspensikan dengan air, kemudian ditambahkan n-hexan, ulangi sampai ekstrak tidak berwarna lagi, residu ditambah $10 \mathrm{ml}$ kloroform, kocok 5 menit. Decanter dalam tabung reaksi yang berisi $10 \mathrm{ml} \mathrm{NaSO} 4$ anhidrat. Filtrat ditambahkan pereaksi Libermen Buchard.

\section{b. Reaksi Pengendapan}

Pengujian dengan reaksi pengendapan dilakukan untuk menguji adanya alkaloid, yaitu:

Sebanyak $500 \mathrm{mg}$ serbuk simplisia, ditambahkan $1 \mathrm{ml}$ asam klorida $2 \mathrm{~N}$ dan $9 \mathrm{ml}$ air, dipanaskan di atas penangas air selama 2 menit, setelah dingin disaring, dan diambil 3 tetes filtrat pada dua kaca arloji:

a. Filtrat ditambahkan 2 tetes mayer LP pada kaca arloji pertama, terbentuk endapan menggumpal berwarna putih

b. Filtrat ditambahkan 2 tetes Bouchardat LP pada kaca arloji kedua, terbentuk endapan berwarna coklat sampai hitam.

\section{HASIL DAN PEMBAHASAN}

Penggunaan tanaman obat oleh masyarakat Sulawesi Selatan telah dikenal dalam buku lontarak pabbura dan merupakan budaya yang diwariskan berdasarkan kearifan lokal masyarakat (etnis) yang terdapat di dalamnya, seperti yang digunakan oleh masyarakat Bulukumba dari etnis Makassar dan Kajang dalam hal pengobatannya selain menggunakan mistik, doa atau kepercayaannya, sanro (dukun) juga menggunakan tanaman untuk mengobati penyakit sebagai obat termasuk penyakit 
kanker. Hasil survei tanaman etnofarmasi terhadap sanro dan tokoh masyarakat desa Lembanna Kecamatan Bontobahari Kabupaten Bulukumba terdapat 5 tanaman berpotensi antikanker, yaitu rumpu' (rumput mutiara), Boyo-boyo (pecut kuda), Gawo (gewor), Tamba robbo' (gendola), dan Bianta (landep). Bianta atau landep daunnya secara etnofarmasi digunakan untuk melunakkan tumor dan juga sebagai obat menghilangkan radang akibat tumor.

Hasil penelitian diketahui daun landep (Barleria prionitis L.) termasuk famili Acanthaceae mengandung golongan senyawa minyak atsiri, alkaloida, glikosida, tannin berupa tannin katekol, saponin, dan flavonoid. Studi aktivitas antibakteri dan antiinflamasi ekstrak pada bagian berbeda tanaman Landep asal Afrika Selatan, menunjukkan antimikroba spektrum luas, dari 21 ekstrak yang digunakan ternyata 20 ekstrak memiliki aktivitas antiinflamasi terhadap cyclooxygenase COX-1 dan 10 ekstrak menunjukkan aktivitas yang baik pada uji COX-2.

Semua ekstrak petroleum eter kecuali ekstrak batang dapat menghambat sintesis prostaglandin dalam COX-1 [13]. Studi antifungi, penghambatan asetilkolinesterase, anti oxidan dan fitokimia tanaman Barleria species menunjukkan aktivitas penghambatan ekstrak daun $B$. Greenii lebih tinggi dibandingkan pada batang dan akar, demikian pula terhadap penghambatan asetilkolinesterase, sebalik-nya pada $B$. albostellata aktivitasnya lebih tinggi pasa batang dibandingkan pada akar dan daun. Uji aktivitas antioksidan terhadap radikal bebas DPPH dengan nilai $\mathrm{EC}_{50}$ antara 6.65$12.56 \mu \mathrm{g} / \mathrm{ml}$ dengan kandungan flavonoid, iridoid and tannin [12]. Hasil uji fraksi iridoid Barleria prionitis Linn. terhadap aktivitas immunomodulator secara in vitro dan in vivo menunjukkan fraksi iridoid potensial sebagai immunostimulan, merangsang mekanisme imun spesifik dan non-spesifik [13].

Tumbuhan Gawo atau Gewor (Commelina benghalensis L.) termasuk kelas monocotyledoneae dengan ciri-ciri adalah herba, tinggi 30-60 cm, batang tegak, bulat, beruas-ruas, lunak, hijau, daun tunggal, berseling, duduk memeluk batang, bunga majemuk, kelopak 3 helai, mahkota bentuk jantung, biru. Buah kotak, bulat telur, hijau. Biji bulat, kecil, hitam. Akarnya serabut. Pada anatomi terdapat jaringan epidermis disertai stomata dengan tipe diasitik, dan pada batang terdapat berkas pengangkut tipe kolateral. Identifikasi kandungan kimia mengandung katekol dan aleuron, polifenol, flavonoid, dan saponin.

Penelitian fitokimia yang lain menunjukkan kandungan metabolit sekunder berupa alkaloid, lactone, kumarin, triterpen, steroid, resin, fenol, tanin, asam amino, kuinon, flavonoid, dan saponin. Alkaloid diterpenoid memiliki aktivitas antibakteri [10]. Flavonoid yang terkandung didalamnya berfungsi sebagai antiokasidan dengan nilai $\mathrm{IC}_{50}=21,53 \mu \mathrm{g} / \mathrm{ml}$, sehingga di Pakistan daunnya dimakan sebagai lalapan atau [5]. Akarnya memiliki aktivitas hepatopretektor dengan kandungan alkaloid dan kandungan flavanoidnya berpotensi antioksidan [14]. Rumput mutiara (Hedyotis corymbosa L) adalah rumput tumbuh rindang berserak, batang bersegi, daun berhadapan bersilang, bunga bentuknya seperti payung berwarna putih, bunga majemuk 2-5, termasuk famili Rubiaceae [7, 17]. dan hasil penelitian tanaman ini mengandung katekol, aleuron, dioksiantrakinon, alkaloid, steroid, dan minyak atsiri. Sifat dari tumbuhan adalah rasa manis sedikit pahit, lembut, netral, agak dingin sudah terkenal sejak nenek moyang untuk menghilangkan demam dan 
hepatoprotektor [3], dan pada masyarakat Bulukumba digunakan juga sebagai obat antikanker.

Kandungan glikosida flavonoid pada rumput mutiara diduga mampu menghambat proses karsinogenesis baik secara in vitro maupun in vivo. Penghambatan terjadi pada tahap inisiasi, promosi maupun progresi melalui mekanisme molekuler antara lain inaktivasi senyawa karsinogen, anti proliferatif, penghambatan angiogenesis, cell cycle arrest, induksi apoptosis dan antioksidan [11].

Tabel 1. Data tanaman etnofarmasi meliputi bagian tanaman, kegunaan, dan cara penggunaannya sebagai anti kanker yang digunakan di etnis Makassar di desa Lembanna Kecamatan Bontobahari Kabupaten Bulukumba.

\begin{tabular}{|c|c|c|c|c|c|}
\hline No & Nama Daerah & $\begin{array}{c}\text { Bagian yang } \\
\text { digunakan }\end{array}$ & Nama Simplisia & Kegunaan & Cara Penggunaan \\
\hline 1. & Bianta & Daun & Barleriae Folium & $\begin{array}{l}\text { peluruh haid, abortivum, dapat } \\
\text { mengurangi rasa sakit dan } \\
\text { dapat melunakkan tumor. }\end{array}$ & $\begin{array}{l}\text { 7-10 lembar Daunnya } \\
\text { direbus dengan } 4 \text { gelas } \\
\text { air hingga } 1 \text { gelas, } \\
\text { diminum } 2 \times 1 / 2 \text { gelas } \\
\text { sehari. }\end{array}$ \\
\hline 2. & Rumpu' & Herba & Hedyotis Herba & $\begin{array}{l}\text { untuk demam, antiradang, } \\
\text { diuretik, menghilangkan racun, } \\
\text { tonsilis, Bron-khitis, radang } \\
\text { usus buntu; hepatitis, infeksi } \\
\text { saluran kemih, bisul, kanker } \\
\text { payudara }\end{array}$ & $\begin{array}{l}\text { Untuk radang herba } \\
\text { ditumbuk dan dibalurkan } \\
\text { pada bagian yg sakit, } \\
\text { untuk kan-ker ditumbuk } \\
\text { dan perasannya diminum, } \\
\text { sehari } 3 \text { x } 1\end{array}$ \\
\hline 3. & Tamba robbo' & Daun & Basellae Folium & $\begin{array}{l}\text { Influenza, radang pada mata, } \\
\text { diare, Rematik, radang } \\
\text { kandung kemih, radang usus } \\
\text { buntu.analgetik, diuretik, dan } \\
\text { antispermatozoa, tumor. }\end{array}$ & $\begin{array}{l}\text { Daunnya direbus dengan } \\
2 \text { gelas air hingga } 1 \\
\text { gelas, diminum } 2 \times 1 \text {. }\end{array}$ \\
\hline 4. & Gawo & Herba & $\begin{array}{l}\text { Commellinae } \\
\text { Herba }\end{array}$ & $\begin{array}{l}\text { herba Gawo digunakan untuk } \\
\text { kanker, mengatasi demam, obat } \\
\text { luka, dan sakit kepala. }\end{array}$ & $\begin{array}{l}\text { Herbanya direbus dengan } \\
3 \text { gelas air hingga } 1 \\
\text { gelas, diminum } 2 \times 1 .\end{array}$ \\
\hline 5. & Boyo-boyo & Daun & $\begin{array}{l}\text { Stachytarphetae } \\
\text { Folium }\end{array}$ & $\begin{array}{l}\text { Infeksi dan batu saluran } \\
\text { kencing, Sakit tenggorokan, } \\
\text { Rematik, Haid tidak teratur, } \\
\text { Batuk, Hepatitis dan } \\
\text { antikanker. }\end{array}$ & $\begin{array}{l}\text { Daun direbus dengan } 3 \\
\text { gelas air hingga } 1 \text { gelas, } \\
\text { diminum } 2 \times 1 .\end{array}$ \\
\hline
\end{tabular}

Tabel 2. Data etnofarmasi dan determinasi tanaman obat yang berpotensi antikanker asal desa Lembanna Kecamatan Bontobahari Kabupaten Bulukumba

\begin{tabular}{|c|c|c|c|c|c|}
\hline No & Nama Daerah & Nama Indonesia & Spesies & Nama Simplisia & Famili \\
\hline 1. & Bianta & Landep & Barleria prionitis L. & Barleriae Folium & Acanthaceae \\
\hline 2. & Tamba robbo' & Gendola & Basella rubra $L$ & Basellae Folium & Acanhtaceae \\
\hline 3. & Gawo & Gewor & $\begin{array}{l}\text { Commelina } \\
\text { benghalensis L. }\end{array}$ & Commellinae Herba & Commelinaceae \\
\hline 4. & Boyo-boyo & Pecut kuda & $\begin{array}{l}\text { Stachytarpheta } \\
\text { jamaicensis }\end{array}$ & $\begin{array}{l}\text { Stachytarphetae } \\
\text { Folium }\end{array}$ & Lorantaceae \\
\hline 5 & Rumpu' & Rumput mutiara & Hedyotis corymbosa $\mathrm{L}$ & Hedyotis Herba & Rubiaceae \\
\hline
\end{tabular}


Tabel 3. Data Skrining Farmakognosi tanaman etnofarmasi yang berpotensi antikanker asal desa Lembanna Kecamatan Bontobahari Kabupaten Bulukumba obat

\begin{tabular}{|c|c|c|c|c|c|}
\hline No & Spesies & Organoleptik & Morfologi & Anatomi & Kandungan kimia \\
\hline 1. & Barleria prionitis L. & $\begin{array}{l}\text { Daun berbau } \\
\text { lemah, rasa agak } \\
\text { kelat. Warna } \\
\text { hijau, batang dan } \\
\text { akar warna coklat, } \\
\text { tidak berbau, dan } \\
\text { tidak berasa. }\end{array}$ & $\begin{array}{l}\text { tinggi antara } 0,5-1,5 \\
\mathrm{~cm} \text {. Batang segi empat } \\
\text { warna coklat. Daun } \\
\text { yang bawah bertangkai, } \\
\text { helaian daun elips } \\
\text { hingga bentuk lanset, } \\
\text { pangkal menyempit } \\
\text { sepanjang tangkai dan } \\
\text { ujung seperti duri. } \\
\text { Bunga kuning, bunga } \\
\text { tunggal dan sering } \\
\text { berkumpul menjadi } \\
\text { bulir. Bunga bentuk } \\
\text { mangkuk. Buah bulat } \\
\text { telur bentuk } \\
\text { memanjang, biji, tiap } \\
\text { ruang } 1 . \text { Akarnya } \\
\text { tunggang. }\end{array}$ & $\begin{array}{l}\text { Epidermis bawah } \\
\text { pada daun Stomata: } \\
\text { Tipe anomositik, } \\
\text { trikoma banyak } \\
\text { pada permukaan } \\
\text { bawah, bentuk } \\
\text { kerucut panjang } \\
\text { rambut } 150 \mu \mathrm{m} \text {, } \\
\text { hablur kalsium } \\
\text { oksalat berbentuk } \\
\text { roset yang besar } \\
\text { dan bentuk prisma. } \\
\text { Kelenjar lisigen } \\
\text { Pada batang dan } \\
\text { berkas pembuluh } \\
\text { kolateral, hipo- } \\
\text { dermis dan } \\
\text { kambium. }\end{array}$ & $\begin{array}{l}\text { minyak atsiri, zat- } \\
\text { zat alkaloida, } \\
\text { glikosida, tannin } \\
\text { katekol, flavonoid } \\
\text { dan alkaloid }\end{array}$ \\
\hline 2. & Basella rubra L & $\begin{array}{l}\text { Daun tidak } \\
\text { berbau, rasa pahit, } \\
\text { warna hijau, } \\
\text { batang tidak } \\
\text { berbau, warna saat } \\
\text { muda ungu dan } \\
\text { saat tua coklat, } \\
\text { rasa agak } \\
\text { pahit,dan akar } \\
\text { berwarna coklat, } \\
\text { rasa sepat. }\end{array}$ & $\begin{array}{l}\text { Daun tunggal yang } \\
\text { bentuknya bulat dengan } \\
\text { panjang } 2-17 \mathrm{~cm} \text {, lebar } \\
1-13 \mathrm{~cm} \text {, tepi rata, } \\
\text { ujung meruncing, } \\
\text { pertu-langan menyirip, } \\
\text { warna daun hijau, } \\
\text { dengan batang } \\
\text { percabangan banyak, } \\
\text { dimulai dan berakar } \\
\text { tunggang. }\end{array}$ & $\begin{array}{l}\text { Irisan melintang } \\
\text { anatomi daun } \\
\text { menunjukkan } \\
\text { adanya stomata tipe } \\
\text { anomositik dan } \\
\text { pada batang } \\
\text { terdapat berkas } \\
\text { pengangkut tipe } \\
\text { kolateral terbuka. }\end{array}$ & $\begin{array}{l}\text { Flavanoid, tannin } \\
\text { dan saponin. }\end{array}$ \\
\hline 3. & $\begin{array}{l}\text { Commelina } \\
\text { benghalensis L. }\end{array}$ & $\begin{array}{l}\text { Daun, batang } \\
\text { berbau, rasa pahit, } \\
\text { warna hijau dan } \\
\text { akar berwarna } \\
\text { putih kecokalatan } \\
\text { dan agak pahit }\end{array}$ & $\begin{array}{l}\text { Herba, tinggi } 30-60 \\
\text { cm. Batang tegak, } \\
\text { bulat, beruas-ruas, } \\
\text { lunak, hijau. Daun } \\
\text { tunggal, berseling, } \\
\text { duduk memeluk } \\
\text { batang, lonjong, tepi } \\
\text { sedikit berombak, } \\
\text { ujung meruncing, } \\
\text { pangkal tumpul, } \\
\text { panjang 3-6 cm, lebar } \\
\text { 1-3 cm, pertulangan } \\
\text { daun sejajar, } \\
\text { permukaan berbulu, } \\
\text { hijau. Bunga majemuk, } \\
\text { kelopak } 3 \text { helai, } \\
\text { mahkota bentuk } \\
\text { jantung, biru. Buah } \\
\text { kotak, bulat telur, } \\
\text { hijau. Biji bulat, kecil, } \\
\text { hitam. Akarnya } \\
\text { serabut. }\end{array}$ & $\begin{array}{l}\text { Daun epidermis dan } \\
\text { stomata tipe } \\
\text { diasitik, pada } \\
\text { batang berberkas } \\
\text { pembuluh tipe } \\
\text { kolateral terbuka, } \\
\text { dengan dindingnya } \\
\text { berlignin. } \\
\text { Penampang } \\
\text { membujur akar dan } \\
\text { batang ditemukan } \\
\text { sel idioblas dan } \\
\text { calcium oksalat } \\
\text { berbentuk prisma. }\end{array}$ & $\begin{array}{l}\text { katekol dan } \\
\text { aleuron, polifenol, } \\
\text { flavonoid, dan } \\
\text { saponin. }\end{array}$ \\
\hline
\end{tabular}


Tabel 3. Data Skrining Farmakognosi tanaman etnofarmasi yang berpotensi antikanker asal desa Lembanna Kecamatan Bontobahari Kabupaten Bulukumba obat( Lanjutan)

\begin{tabular}{|c|c|c|c|c|c|}
\hline 4. & $\begin{array}{l}\text { Stachytarpheta } \\
\text { jamaicensis }\end{array}$ & $\begin{array}{l}\text { Daun, batang dan } \\
\text { akar berbau khas } \\
\text { dan tajam, daun } \\
\text { warna hijau, rasa } \\
\text { pedas dan agak } \\
\text { pahit. Batang } \\
\text { coklat, rasa agak } \\
\text { pahit. Akar warna } \\
\text { coklat tua, rasa } \\
\text { pahit. }\end{array}$ & $\begin{array}{l}\text { Daun berhadapan } \\
\text { bentuk bulat telur, } \\
\text { tunggal dengan } \\
\text { panjang } 4-4 \mathrm{~cm} \text {, lebar } \\
3-6 \mathrm{~cm} \text {, tepi bergerigi, } \\
\text { ujung runcing, hijau } \\
\text { tua. akar serabut. Pada } \\
\text { batang berbentuk bulat } \\
\text { panjang beruas-ruas. } \\
\text { Bunga majemuk } \\
\text { tersusun dalam bulir } \\
\text { yang memanjang, } \\
\text { mirip pecut, } \\
\text { panjangnya } 4-20 \mathrm{~cm} \text {. } \\
\text { warna ungu. Buah } \\
\text { berbentuk garis, berbiji } \\
2, \text { berbentuk jarum } \\
\text { berwarna hitam. }\end{array}$ & & $\begin{array}{l}\text { katekol, lignin, } \\
\text { dioksiantrakinon } \\
\text { glikosida, flavonoid } \\
\text { dan alkaloid. }\end{array}$ \\
\hline 5 & $\begin{array}{l}\text { Hedyotis } \\
\text { corymbosa } \mathrm{L}\end{array}$ & $\begin{array}{l}\text { Warna daun hijau, } \\
\text { rasa pahit, dan } \\
\text { tidak berbau. } \\
\text { Bentuk batang } \\
\text { bulat berwarna } \\
\text { coklat, tidak } \\
\text { berbau dan rasa } \\
\text { pahit. Pada akar } \\
\text { berwarna } \\
\text { kecoklatan, rasa } \\
\text { pahit, tidak } \\
\text { berbau. }\end{array}$ & $\begin{array}{lr}\text { Daun: } & \text { tunggal, } \\
\text { menyirip, } & \text { berhadap } \\
\text { bersilang, } & \text { ujung } \\
\text { runcing, } & \text { pangkal } \\
\text { hampir duduk, tepi } \\
\text { rata, daging daun tipis } \\
\text { lunak. Warna pada } \\
\text { waktu muda hijau } \\
\text { kemerahan dan saat tua } \\
\text { hijau kemerahan, } \\
\text { permukaan } \\
\text { berwarna hijau tua, } \\
\text { kasar, permukaan } \\
\text { bawah daun warna } \\
\text { hijau muda. Batang } \\
\text { tidak berkayu, bentuk } \\
\text { bulat, percabangan } \\
\text { banyak, permukaan } \\
\text { batang kasar, warna } \\
\text { batang muda coklat } \\
\text { muda dan batang } \\
\text { coklat tua. Akar } \\
\text { serabut. }\end{array}$ & $\begin{array}{l}\text { Epidermis bawah } \\
\text { dan stomata tipe } \\
\text { diasitik dan sistem } \\
\text { jaringan } \\
\text { pengangkut pada } \\
\text { batang dan akar } \\
\text { adalah kolateral } \\
\text { terbuka. }\end{array}$ & $\begin{array}{l}\text { katekol, aleuron, } \\
\text { diokstrakinon, } \\
\text { alkaloid, steroid, } \\
\text { dan minyak atsiri. }\end{array}$ \\
\hline
\end{tabular}

Herba gendola (Basella rubra L) merupakan tanaman budidaya yang lebih dikenal dengan nama Binahong berdaun tunggal letak berhadapan, bentuknya bulat termasuk famili Acanthaceae [7, 17], ini memiliki efek analgetik, diuretik, dan antispermatozoa. Saponin pada daun gendola memiliki kemampuan untuk menghemolisis darah merah. Gendola juga memiliki efek menghilangkan panas dalam, racun dan mengeluarkan organisme penyebab sakit dari darah [6]. Senyawa flavanoidnya berkhasiat sebagai anti oksidan dan diduga juga berpotensi sebagai antikanker. 
Pecut kuda (Stachytarpheta jamaicensis) adalah tanaman dengan ciri daun letak berhadapan, berupa daun tunggal tepi bergerigi, ujung daun runcing, bunga majemuk tersusun dalam poros bulir yang memanjang, seperti pecut, sehingga disebut pecut kuda ini termasuk famili Loranthaceae [15], uji kandungan kimia menunjukkan bahwa tanaman ini positif mengandung katekol, lignin dan dioksiantrakinon. Serta mengandung glikosida flavonoid dan alkaloid yang diduga berkhasiat sebagai antikanker. Flavonoid dari spesies lain yaitu ekstrak methanol $S$. indica bersifat sitoprotrotektor dan antioksidan terhadap DPPH dengan nilai $\mathrm{IC}_{50}=40,07 \mu \mathrm{g} / \mathrm{ml}$ [16]

Efek flavonoid sebagai antikanker dapat bersifat kemopreventif dan kemoterapi dengan mekanisme menginaktifkan senyawa karsinogen, antiproliferasi, memperbaiki siklus sel, menginduksi apoptosis dan diferensiasi, menghambat angiogenesis, antioksidan dan mencegah resitensi dari kombinasi penggunaan obat [11].

\section{KESIMPULAN}

Hasil penelitian didapatkan lima tanaman etnofarmasi yang potensial untuk pengobatan kanker yaitu daun (Barleria prionitis L.) Famili Acanthaceae, gewor (Basella rubra L) Famili Acanhtaceae, pecut kuda (Stachytarpheta jamaicensis) Famili Loranthaceae, rumput mutiara (Hedyotis corymbosa L.) family Rubiaceae dan gondola (Commelina benghalensis L.) famili Commelinaceae, dengan kandungan kimia mengandung flavanoid, alkaloid, dan tanin. Kandungan flavonoid, dan alkaloid dalam tanaman berpotensi untuk digunakan sebagai obat kanker.

\section{DAFTAR PUSTAKA}

1. B.V. Ghule, P.G. Yeole, 2012. In Vitro And In Vivo Immunomodulatory Activities Of Iridoids Fraction From Barleria prionitis Linn., Journal of Ethnopharmacology, Volume 141, Issue 1.

2. Cuéllar Armando, 2010, Preliminary Phytochemical And Antimicrobial Evaluation Of The Fresh And Dried Whole Plant Extracts From Commelina Benghalensis, Rev. Colombiana cienc. Anim. 2(1)

3. Dalimarta, 2006. Atlas Tumbuhan Obat Indonesia, Jilid 3, Trubus Agriwidya, Jakarta.

4. Direktorat Jenderal Pengawasan Obat dan Makanan., 1989,-1995 Materia Medika Indonesia, Jilid I-VI, Departemen Kesehatan Republik, Jakarta

5. Dixon, R.A, Dey, P.M, Lamb, C.J, 1983. Phytoalexins, Enzymology and Molecular Biology, Adv. Enzymol. 55:1-69.

6. Fauzi R. Kusuma and B Muhammad Zaky. 2005. Tumbuhan Liar Berkhasiat Obat. Agro Media. Pustaka..Yogyakarta

7. Gembong T., 1987. Taksonomi Tumbuhan Obat-Obatan, Gadjah Mada University Press, Yogyakarta.

8. Hamid A., 2008. Pengobatan Tradisional Berbasis Lontara di Sulawesi Selatan, Dinas Kebudayaan Sulawesi Selatan.Makassar.

9. Hasan, S. M, et al, 2009, DPPH Free Radical Scavenging Activity Of Some Bangladeshi Medicinal Plants, Journal of Medicinal Plants Research Vol.3 (11).

10. Omulokoli, E.; Khan, B.; Chhabra, S.C. 1997. Antiplasmodial Activity of Four Kenyan Medicinal Plants. J. Ethnopharmacol. 56:133137.

11. Ren, W., et al., 2003. Flavonoids: Promising Anticancer Agents, Medicinal Research Reviews, Vol. 23, No. 4.

12. S.O. Amoo, A.R. Ndhlala, J.F. Finnie, J. Van Staden, 2011. Antifungal, Acetylcholinesterase Inhibition, Antioxidant And Phytochemical Properties Of Three Barleria species, South African Journal of Botany, Volume 77, Issue 2.

13. S.O. Amoo, J.F. Finnie, J. Van Staden, 2009. In Vitro Pharmacological Evaluation Of Three Barleria species, Journal of Ethnopharmacology, Volume 121, Issue 2.

14. Sambrekar et al, 2009. Protective Activity Of Commelina Benghalensis- Root Extracts Against Paracetamol Induced Hepatic Damage In Wistar Rats, Pharmacologyonline 3: 836844. 
15. Sutrisno, B., 1998. Taksonomi Spermatophyta Untuk Farmasi, Fakultas Farmasi, Universitas Pancasila, Jakarta

16. Zafar Z., Muralidhar Talkad, Chinmay Bandopadhyay, and Anil Kumar H.V, 2010. A Safety Evaluation of Starchytaperta indica, a
Potent Traditional Anti-oxidant Medicinal Plant, European Journal of Scientific Research, Vol. 46. No.1.

17. Van Steenis, dkk., 2006. Flora, Untuk Sekolah di Indonesia, Pradnya Paramita., Jakarta. 